\title{
"Estatuomanía" en América Latina. Aproximaciones a la escultura conmemorativa de fines de siglo XIX y comienzos del siglo XX*
}

\author{
"Estatuomanía" in Latin America. \\ Approaches to the commemorative sculpture \\ of the late 19th and early 20th centuries
}

\author{
Carolina Vanegas Carrasco** \\ Universidad Nacional de San Martín \\ Recibido: 12 de febrero de 2020 \\ Aceptado: 5 de abril de 2020
}

\begin{abstract}
RESUMEN
Una serie de obras en diferentes ciudades de América Latina guían una reflexión sobre los procesos de creación, los usos y las prácticas alrededor de la escultura conmemorativa en su momento de mayor auge: el fin del siglo XIX y el comienzo del siglo XX. La mirada comparativa pretende mostrar algunas sincronías y asincronías de estos procesos, así como proponer una serie de problemas y autores a considerar en el estudio de la escultura conmemorativa de la región.
\end{abstract}

Palabras clave: escultura conmemorativa, monumento, arte latinoamericano, siglo XIX.

\begin{abstract}
A series of works from different cities in Latin America guide a reflection on the processes of creation, uses and practices around the memorial sculpture at its peak: the end of the nineteenth century and the beginning of the twentieth century. The comparative view aims to show some synchronies and asynchronies of these processes, as well as to propose a series of problems and authors to consider in the study of the commemorative sculpture of the region.
\end{abstract}

Keywords: commemorative sculpture, monument, Latin American art, 19th Century.

* La investigación aquí presentada tiene como punto de partida el primer capítulo de la tesis doctoral Disputas monumentales. La celebración del Centenario de la Independencia de Colombia a través de sus monumentos conmemorativos (Bogotá, 1910), dirigida por la Dra. Laura Malosetti Costa y presentada en el programa de doctorado en historia del Instituto de altos estudios sociales (IDAES) de la Universidad Nacional de San Martín, Buenos Aires, Argentina en 2015

** Carolina Vanegas Carrasco. Egresada de Artes Plásticas con énfasis en Historia y teoría del arte (Universidad Nacional de Colombia). Doctora en Historia y Magíster en Historia del arte argentino y latinoamericano del Instituto de Altos Estudios Sociales de la Universidad Nacional de San Martín (IDAES-UNSAM, Argentina). 


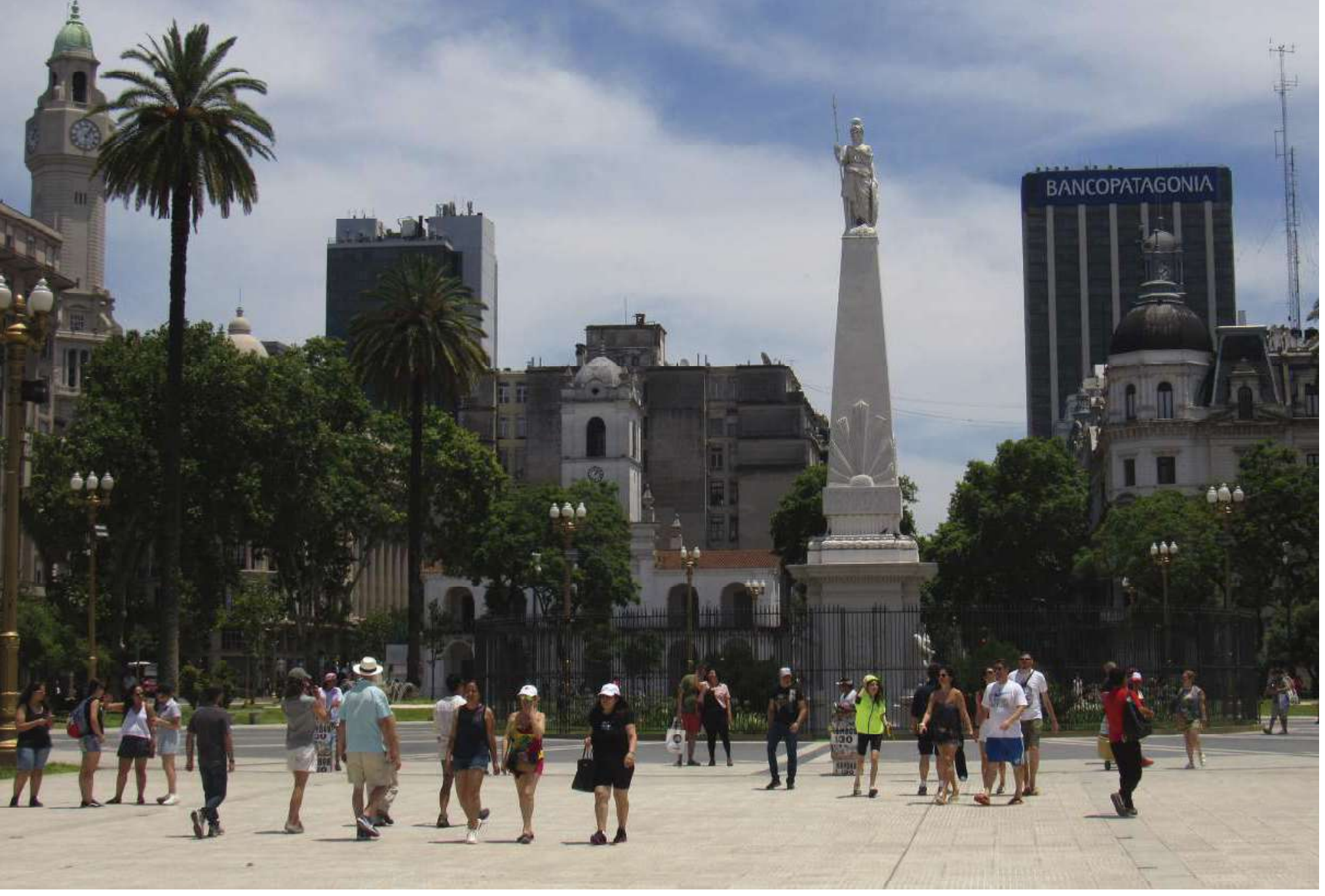

Pirámide de Mayo. Plaza de Mayo, Buenos Aires. Foto Elio Martuccelli, 2019

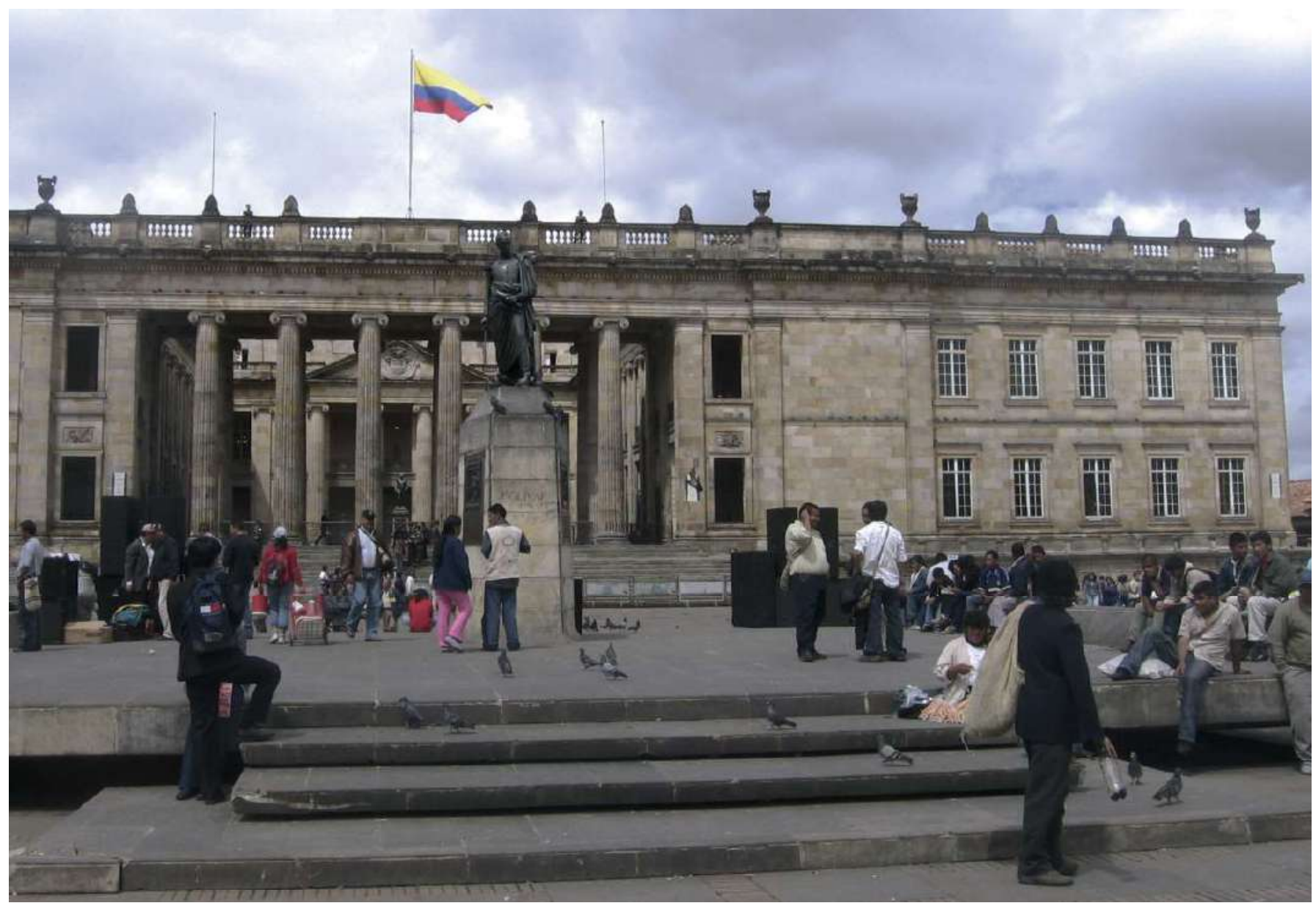


En las últimas dos décadas hemos presenciado un cambio de paradigma respecto de las esculturas conmemorativas. En los medios de comunicación se han multiplicado las imágenes que nos muestran la caída de monumentos en diferentes lugares del mundo o las intervenciones en muchas de ellas por obra de artistas y activistas. Gran parte de estas acciones se relaciona con la puesta en cuestión de personajes del pasado a través de sus representaciones esculturales como actos simbólicos que trascienden a la escultura como tal. En ese sentido, el presente texto pretende aportar una mirada a las lógicas de creación de este tipo de obras y a las prácticas asociadas a ellas, como una forma de contribuir a la comprensión de las mismas en su contexto, en el momento de su mayor auge entre la segunda mitad del siglo XIX y comienzos del XX.

Específicamente para América Latina, este periodo coincidió con la consolidación de narrativas nacionales que corrió paralelo al de la modernización de las ciudades, por lo que es importante comprender a la escultura pública como una práctica con profundos alcances simbólicos en las esferas política y urbana. Con el presente artículo buscamos establecer un conjunto de variables a considerar en su estudio, a partir de algunos casos significativos en términos políticos, materiales, urbanísticos o artísticos. Si bien es necesario establecer diferencias en los procesos históricos y simbólicos de los países latinoamericanos, se puede afirmar que al examinarlos en conjunto en el siglo XIX y comienzos del $X X$, respondieron a unos procesos generales similares. Esta perspectiva comparativa es poco frecuente, en parte, debido a la estrecha relación entre la escultura conmemorativa y las historias políticas nacionales. Un recuento de este tipo se justifica debido a la todavía escasa producción académica sobre escultura conmemorativa en Latinoamérica desde la historia cultural, una perspectiva necesaria para complejizar la mirada sobre este tipo de obras y sus sentidos simbólicos.

La creación de la mayor cantidad de monumentos conmemorativos en las principales ciudades latinoamericanas se produjo entre 1860 y 1930, una etapa que José Emilio
Burucúa y Fabián Alejandro Campagne caracterizaron como "monumental" en la que

la historia hubo de ser leída en los textos literarios y, a la par, en una trama figurativa e iconográfica que, mediante los monumentos (columnas, estatuas, conjuntos escultóricos, tumbas, grandes ciclos decorativos de pintura histórica), se insertaba en el tejido material de la ciudad, al aire libre, en sus cementerios o en el interior de sus palacios públicos. (1994, pp. 351-352)

Las ideologías republicanas permanecían al ámbito cerrado de las élites ilustradas y las tentativas de transvasar ese pensamiento fuera de ellas tenían que ser realizadas con símbolos más universales, como las imágenes, las alegorías y los mitos. Dentro de este repertorio, en la escultura conmemorativa "se percibe de manera más obvia que en otros tipos de obras las cualidades tangibles de la ideología, la materialidad del discurso" (Majluf, 1994, p. 9). Este fue uno de los lugares en los que se libró "la batalla por el imaginario popular republicano", de acuerdo con Murilo de Carvalho quien caracterizó la creación de este imaginario como parte integrante de la legitimación de cualquier régimen político, "donde las sociedades definen sus identidades y objetivos, definen sus enemigos, organizan su pasado, su presente y su futuro" (Murilo de Carvalho, 1997 [1990], p. 17). Puede afirmarse que el momento de mayor producción o "estatuomanía" dentro de la "etapa monumental" fue la celebración de los centenarios de la independencia de las naciones americanas ocurrido entre 1908 y 1922. Fue un momento en el que "toda la polémica estética, cultural y política sobre el presente se hará inseparable de una perspectiva sobre el pasado" (Gorelik, 2004 [1998], p. 207).

Para las élites de América Latina la incorporación de monumentos no sólo apoyó sus intenciones de legitimación política sino que se constituyó -no sin contradicción- en una práctica introductora de aspectos centrales en el pensamiento decimonónico como lo eran las nociones de "modernidad", "progreso" y "civilización", identificadas estrechamente con Francia, la cual se había consolidado como el faro cultural del momento. $\mathrm{Y}$ el lugar en que estas transformaciones se hicieron más visibles fue precisamente la ciu- 
dad. En este sentido, resulta esclarecedora la reflexión que la historiadora peruana Natalia Majluf hace sobre este nuevo espacio público y el papel de la escultura conmemorativa en este proceso:

Si durante el XIX las calles, las plazas, las alamedas eran propiedades estatales, y por ende públicas, ¿a quién pertenecían durante la época colonial? En última instancia, estos lugares debían pertenecer al Rey, y el espacio urbano era formalmente una frontera de poder. La escultura del XIX, por medio de su emplazamiento en lugares considerados públicos, intenta apropiarse de las calles, reclamándolas para el Estado y para la nación. (1994, p. 9)

Desde el punto de vista del urbanismo resulta pertinente la propuesta de historia cultural de las representaciones de la ciudad de Adrián Gorelik, en la que plantea una dependencia de doble vía entre los artefactos urbanos y la cultura. En esta concepción el autor considera esencial la comprensión de la noción de espacio público en términos más amplios, como "el producto de una interpretación sobre la relación entre la forma urbana y la cultura política de un momento determinado de la historia" (Gorelik, 2004 [1998], pp. 16-19). Las coincidencias en los cambios de las principales ciudades latinoamericanas son analizadas por José Luis Romero en su libro Latinoamérica: las ciudades y las ideas en donde señala que junto con la expansión económica "una influencia decisiva ejercía sobre las nuevas burguesías el modelo de la transformación de París, imaginada por $\mathrm{Na}$ poleón III y llevada a cabo por el barón de Haussmann" (Romero, 2007 [1976], p. 275). Incluso en las ciudades a las que no llegó esta expansión "quedó flotando en el ambiente como una vaga aspiración a proporcionar a cada ciudad provinciana algo que le permitiera creerse metrópoli" (2007 [1976], p. 283). Estas diferencias se produjeron tanto en la dupla capital-región así como entre las ciudades de mayor desarrollo estructural y otras capitales latinoamericanas.

El énfasis en la transformación física e incorporación de monumentos en las capitales, según Gorelik, se explica debido a que

desde el punto de vista de la cultura urbanística [aunque no exclusivamente] era razonable suponer [...] que la mejor celebración de las fiestas debía ser la propia puesta a punto de la ciudad, como monumento y como legado, en una ecuación irrebatible en el periodo para la mirada oficial: ciudad capital / imagen de nación. (2004 [1998], p. 187)

A su vez Laura Malosetti afirma:

Insisto en hablar de ciudad a pesar de que los discursos en la época fueron en términos de "nacionalidad" para destacar la profunda brecha existente entonces entre el desarrollo de Buenos Aires y el interior del país, su comunicación fluida con las metrópolis europeas y su pretensión de "ser" la nación. (2007 [2001], p. 30)

Independientemente de las posibilidades reales de transformar físicamente la ciudad, esta aspiración metropolitana se hizo presente mediante un progresivo cambio en las costumbres de dichas sociedades, en donde igualmente el modelo europeo era el referente.

Pero la adopción de estos modelos no sólo apuntaba a la creación de una ciudad burguesa para la consolidación de estas ideas sino que aspiraba a consolidar una imagen de ciudad que les permitiera ser incluidos en la "comunidad imaginada" de la "civilización" europea. En palabras del historiador colombiano Frédéric Martínez:

El viaje al Viejo Mundo, por la ineludible confrontación que implica con los prejuicios imperantes en la percepción europea de América del Sur refuerza el sentimiento nacional, el deseo de trabajar para el reconocimiento internacional de la ignorada patria [... L La búsqueda de modelos importables conjugada con el ejercicio de un patriotismo militante es en definitiva la combinación que dará su particular textura a la experiencia europea. (2001, pp. 243-244)

En la medida de la capacidad de cada urbe se hicieron cambios grandes o pequeños en los principales espacios simbólicos de la ciudad $y$ en este proceso fue fundamental el papel que jugó la escultura conmemorativa tanto en su dimensión decorativa como en la simbólica, en tanto las dos fueron fundamentales y complementarias en la consolidación de las identidades nacionales. Desde esta perspectiva se concibe que el Estado utilizara el discurso del ornato "para apropiarse del espacio urbano, para ordenarlo y controlarlo. Existía una creencia desmedida en la efecti- 
vidad de las obras de ornato para definir el progreso de la ciudad" (Majluf, 1994, p. 20)

La adquisición de otros elementos de ornato fue favorecida también por los avances técnicos que permitieron la reproducción de fuentes, faroles y demás mobiliario que fue parte fundamental de esta nueva ciudad "a la europea". Dentro de este proceso destacó la inmensa producción y distribución de la fundición en hierro de la firma Val D’Osne “cuyo acervo hacia 1900 consistía en aproximadamente 40.000 modelos de piezas industriales, mecánicas, utilitarias y artísticas" (Alves, 2009, p. 58). Otro tanto podría decirse de las obras en mármol que también se vendían por catálogo e incluían además de bustos y estatuas, elementos decorativos como columnas y pilas de agua, comúnmente a cargo de marmolistas que se dedicaban a su importación y ensamblaje (Majluf, 1994, pp. 28-29). La incorporación de estos elementos de ornato permitía un acercamiento aún mayor al objetivo de construir ciudades similares a las que les habían dado inspiración, particularmente París, "la capital del mundo [...] la ciudad universal [en donde] se elaboran las bellezas que nos fascinan y las ideas que nos guían" como escribía en su correspondencia el chileno Benjamín Vicuña Subercaseaux (citado por Ibarra, 2005, p. 145). Modelos estudiados incluso antes de conocerlos de primera mano, como bien lo ilustran las palabras de Carlos Holguín, presidente de Colombia entre 1888 y 1892 :

Estoy sorprendido de lo que yo conocía en París por conversaciones y libros o pinturas. Desde que eché a ver por todas partes edificios, columnas, estatuas, bulevares, plazas, sitios y paseos que como me los sabía de memoria, apenas los he visto los he reconocido. (En Martínez, 2001, p. 206)

A diferencia del caso de la pintura, en donde en el paso de la colonia a la independencia principalmente hubo una modificación de temas y modelos, en la escultura el principal cambio que se produjo en el siglo XIX fue de técnica y materiales. Los conocimientos que poseían los escultores americanos activos durante el antiguo régimen no eran los requeridos para realizar estas nuevas obras, ya que dominaba principalmente la talla en madera, que difícilmente podía adaptarse a los requerimientos necesarios para ser instalada al aire libre. Adicionalmente a las cuestiones prácticas, el modelo europeo indicaba que las obras debían realizarse con materiales "nobles": mármol y bronce. En el caso del mármol el problema fue principalmente la consecución del material. Se consideraba ideal que se utilizara mármol de Carrara, que en Europa era muy apreciado por su ausencia de vetas y blancura, este mármol estaba cargado con el aura de perfección de la tradición clásica, hegemónica en la tradición estética occidental. Hubo esfuerzos sostenidos de buscar y usar piedras locales para la creación de obras pero fueron proyectos aislados y no se conoce ningún caso en que se hiciera de manera sistemática. Una de las más notables producciones que ilustran este caso son las alegorías de la libertad y de América talladas en piedra de villería "que semeja mármol blanco" por Pedro Patiño Ixtolinque (17741834) para el mausoleo del prócer mexicano José María Morelos (1765-1815) hacia 1825. (Imagen 1)

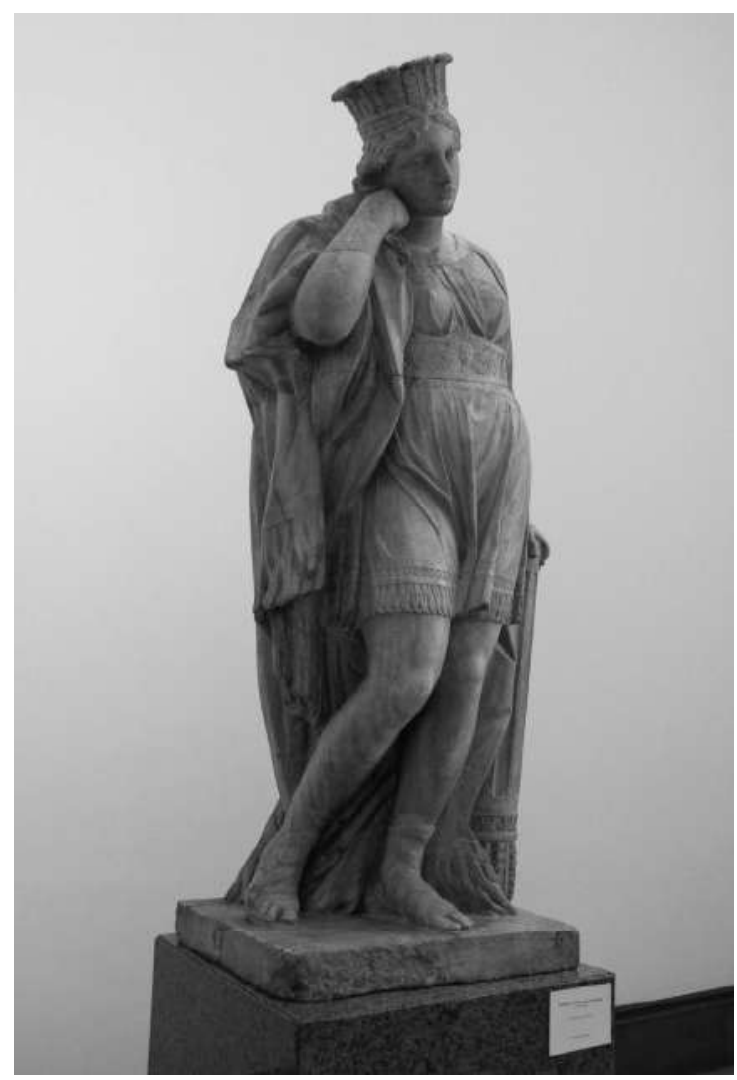

Imagen 1. Alegoría de América para el mausoleo del prócer mexicano José María Morelos hacia 1825 con la piedra que provenía del pedestal de la estatua ecuestre de Carlos IV. Autor: Pedro Patiño Ixtolinque (1774-1834). Museo Nacional de Bellas Artes, México DF. Fotografía: C. Vanegas. 
Sin embargo el uso de este material no pretendía ser una propuesta de uso de materiales locales para la estatuaria, aunque si tenía una importante connotación política, pues la piedra provenía del pedestal de la estatua ecuestre de Carlos IV. Mármoles de Puebla y granitos mexicanos estuvieron en el fallido proyecto de la estatua de Colón proyectada por Manuel Vilar e impulsada por Maximiliano hacia 1865, sin que -como se dijo- tuviera ninguna continuidad. En Colombia, sería un escultor italiano, Mario Lambardi, quien propuso el uso de una piedra local que imitaba el mármol, la cual era extraída de Balsillas, una cantera de piedra arenisca blanca cercana a la capital, Bogotá. El rechazo que produjo el uso de este material se hizo

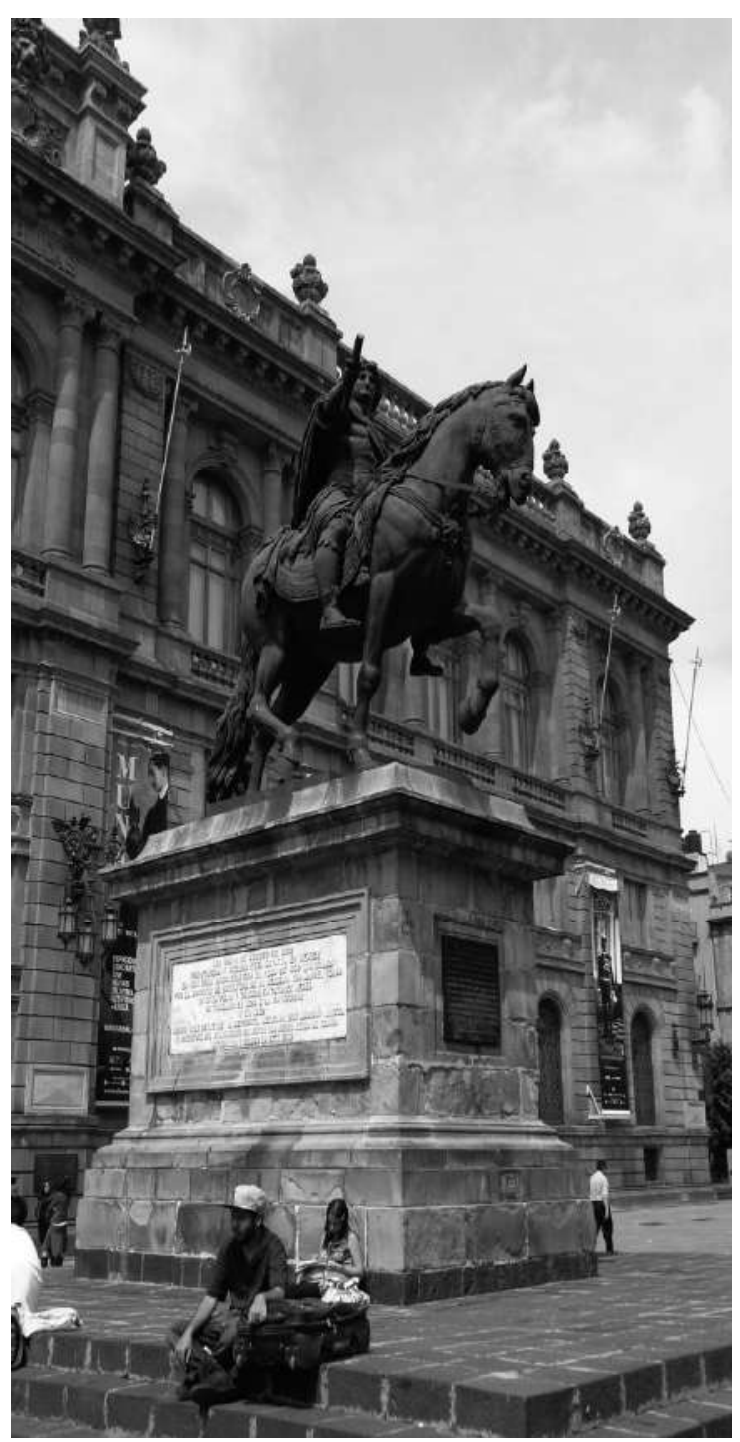

Imagen 2. Estatua ecuestre de Carlos IV. 1796-1803. Autor: Manuel Tolsá. Bronce. Vista actual frente al Museo Nacional de Arte, México, DF. Fotografía: C. Vanegas evidente en la pronta destrucción y degradación de las pocas obras que hizo, con las que además formó a una generación de escultores, que como él, fueron marginados de la historia del arte local (Cfr. Vanegas, 2013). Incluso en un caso más exitoso que éste, como fue el uruguayo a comienzos del siglo $X X$, en el que artistas italianos usaron mármoles de las canteras de Burgueño en Maldonado, que llamaron "la nueva Carrara", se estableció una jerarquización del material en donde se asignaban a éste los detalles y se dejaban en mármol de Carrara los más representativos (Beltrami, 2007, pp. 281-286). Para el escultor francés Louis Rochet, las piedras que encontró en Rio de Janeiro le parecieron "de inferior calidad" para ser parte del pedestal del monumento a Pedro I (Coli, 2010, s.p.).

Con respecto a la fundición de bronce de gran tamaño, la situación era muy distinta ya que era un procedimiento que se usaba especialmente en la producción de armamento, campanas y en algunos lugares de decoración arquitectónica. Solo hemos identificado obras de bronce producidas localmente en el siglo XVIII en Brasil y en México; en este último, la estatua ecuestre de Carlos IV, que fue la única obra en este material del escultor Manuel Tolsá. (Imagen 2) La fundición artística en Río de Janeiro, por su parte, funcionó en la Casa del Tren (de artillería) y tuvo en Valentim da Fonseca e Silva (conocido como Mestre Valentim, 1745-1813) a su más destacado artífice. Su ámbito era el de la decoración urbana y arquitectónica y las "primeras estatuas fundidas en el país" fueron las figuras de Eco y Narciso para la Fuente de los Patos (Chafariz das Marrecas).

Quienes han investigado estos dos casos coinciden en afirmar que la práctica de la fundición no tuvo continuidad, en gran parte por los enormes cambios políticos surgidos en las primeras décadas del siglo XIX (en México el proceso de Independencia y en Brasil, la instalación de la corte portuguesa en Río), así como por el agotamiento de las minas Novohispanas como lo demostró la carencia de azogue y calamina (Chiva, 2009, p. 225) y "la franca decadencia de las "Minas Gerais"" (Abrantes, 1979, p. 25). Solo entre fines del siglo XIX y comienzos del XX se lograría en estos y otros países el establecimiento de 
fundiciones artísticas ${ }^{1}$ para atender tanto las necesidades conmemorativas como de ornato urbano, aunque siempre en desventaja con la ya industrializada producción europea. De acuerdo con Natalia Majluf es interesante pensar en que justamente el material era uno de los parámetros que instalaba estas obras dentro de las coordenadas de "modernidad y progreso":

En Europa el mármol y el bronce podían ser sinónimos de una venerable tradición que llevaba hasta los orígenes de la civilización en la antigüedad clásica, pero para el Perú [y la mayoría de las naciones americanas] del ochocientos fueron sinónimos del futuro. (Majluf, 1994, p. 31)

La influencia europea pasó de ser modélica para hacerse real y patente al encargar dichas obras a artistas italianos, alemanes, franceses y españoles especialmente, para ser instaladas en las ciudades latinoamericanas. Si bien en un primer momento pudo haberse tenido en cuenta el hecho de la falta de artistas y materiales para realizar las obras localmente, más adelante estas ideas persistieron y se privilegiaron los proyectos de artistas europeos frente a los de artistas locales que se habían formado para realizar dichas obras. En esta decisión estaba implícito un cierto consenso sobre la superioridad artística y técnica europea, sin contar con el "aura de civilización" que podía significar el instalar obras enteramente realizadas en Europa. Comúnmente, las juntas encargadas de gestionar las obras se encontraban ante la disyuntiva de hacer concursos internacionales -que le daban mucho prestigio a la creación misma de la obra- y el encargo directo de las obras que generalmente iba en contra de la consolidación de campos profesionales nacionales. (Gorelik, 2004 (1998), p. 229)

Este carácter modélico de París llegó a un exacerbado punto en el caso del Monumento al Combate del 2 de mayo de 1866 en Lima. (Imágenes za y 3b) Construido en 1874 , era una obra de gran importancia simbólica pues conmemoraba el triunfo sobre Espa$\tilde{n} a^{2}$. Se hizo un concurso en París, en donde no se tuvo en cuenta el lugar en la que sería instalada. Después de ordenarse la ejecución de la obra, el gobierno peruano subsidió un simulacro del monumento con las piezas de

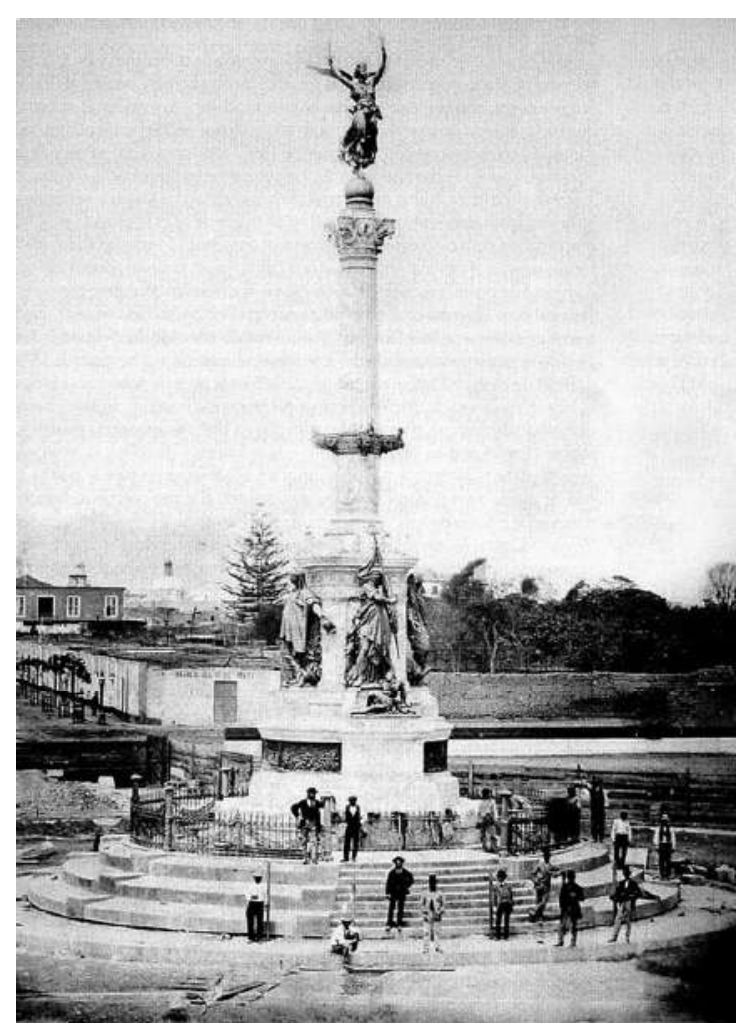

Imagen 3a. Monumento al Combate del 2 de mayo, 1874. Bronce. Lima. Foto tomada de https://medium. com/@culturaparalima/conoce-la-historia-de-la-plazados-de-mayo-f4d379065fg6

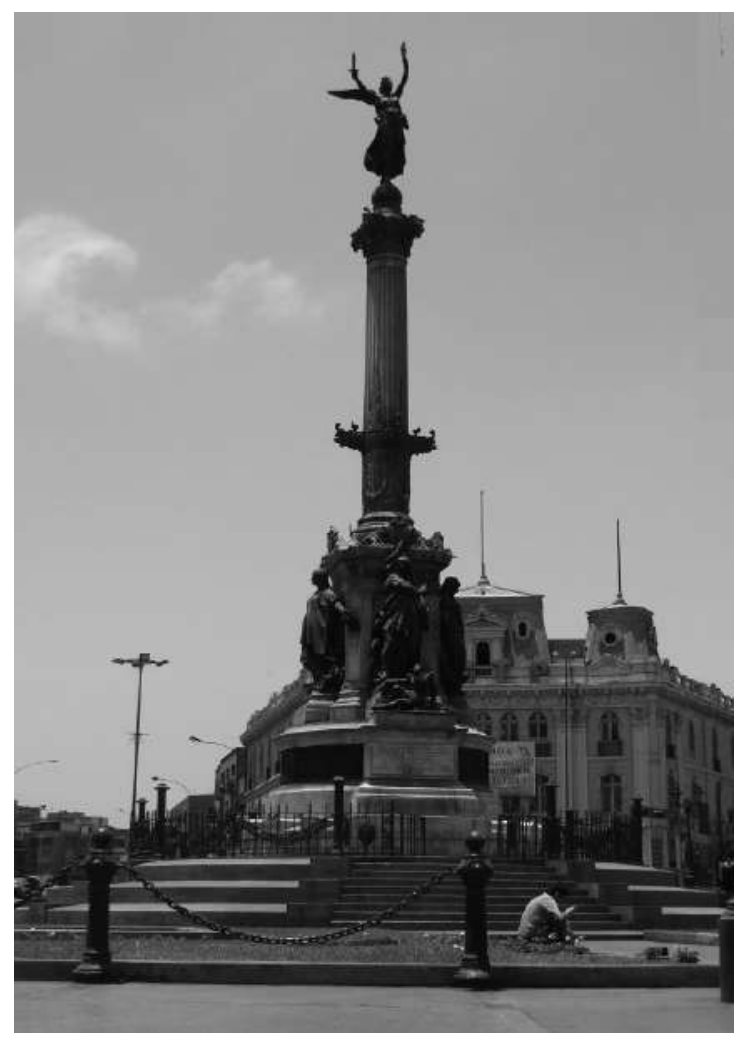

Imagen 3b. Monumento al Combate del 2 de mayo, Lima. Vista actual. Foto: Elio Martuccelli, 2015 
bronce que ya estaban fundidas que fue ubicado frente al Palacio de la Industria en los Campos Elíseos, en ocasión de la Exposición de Bellas Artes de París de 1872. Es así que los peruanos conocieron su monumento primero a través de la fotografía, ubicado en París. A través de esta imagen, señala Natalia Majluf, también se importó el modelo urbanístico y además ayudó a producir el espacio que más tarde lo habría de enmarcar. Posteriormente fue ubicada en Lima, en un lugar conocido durante la colonia como el "óvalo de la reina", que contrastaba fuertemente con su entorno y produjo un importante crecimiento urbanístico a su alrededor (Majluf, 1994).

La elección de escultores extranjeros muchas veces puso en segundo plano una pretendida "precisión histórica" o el "parecido" con los personajes representados (Cfr. Gutiérrez Viñuales, 2004, pp. 120-143). Las polémicas locales que surgieron por esta causa se produjeron como una demanda de semejanza con los modelos y otras veces por la "demanda de figuras arquetípicas para las necesidades fundacionales de una imaginería que se piensa en su capacidad no representativa sino de reproductibilidad icónica" (Gorelik, 2004 [1998], p. 217). Un caso ilustrativo es el rechazo a la escultura de Domingo Faustino Sarmiento (1811-1888) encargado al célebre

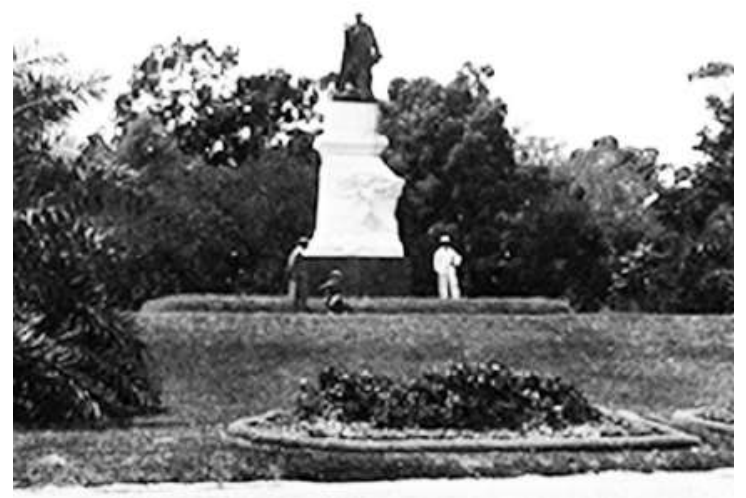

Imagen 4a. Monumento a Domingo Faustino Sarmiento en el Parque Tres de Febrero, Buenos Aires. 1900. Foto: Fondo Thays, Archivo Histórico de la Ciudad de Buenos Aires. escultor francés Auguste Rodin (1840-1917), en el cual, al parecer, el rechazo estético estuvo por encima de las discusiones a la memoria del homenajeado, como lo corrobora la nota de prensa en que se afirmó lapidariamente: "Es difícil concebir algo más feo, vulgar, casi repulsivo y, por lo tanto menos parecido a Sarmiento que el perfil de su estatua". ${ }^{3}$ Esta fealdad estaba relacionada con la falta de semejanza con el rostro del modelo $y$, sin duda, con una lectura frenológica en auge por aquel momento. Imposibilitaba la idea de "reproductibilidad icónica", con lo que se explica el que se solicitara al escultor italiano radicado en Argentina, Víctor de Pol (1865-1925) que hiciera la medalla conmemorativa de la inauguración del monumento, en la que campea un perfil verista del rostro de Sarmiento. Atender a las contradicciones surgidas en la producción artística para las conmemoraciones resulta muy productivo para comprender cómo los mediadores fueron consolidando a través del tiempo una separación entre los dominios de la producción histórica y los de la artística. La eficacia de esta separación en la escultura conmemorativa -tanto en su creación como en su posterior análisis- puede verse en que cada vez más entró en el dominio del discurso histórico y menos en el artístico. (Imágenes 4a, 4b y 5)

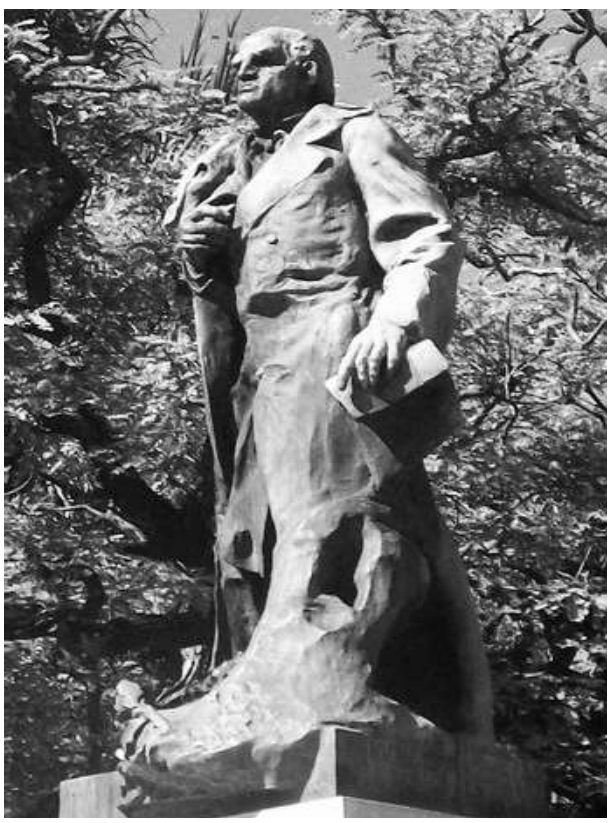

Imagen 4b. Monumento a Sarmiento. 1900. Autor: Auguste Rodin. Bronce y mármol. Plaza Sicilia, Buenos Aires. Foto tomada de https:// es.m.wikipedia.org/wiki/Archivo:Domingo_Sarmiento_Rodin_Palermo_III.jpg 


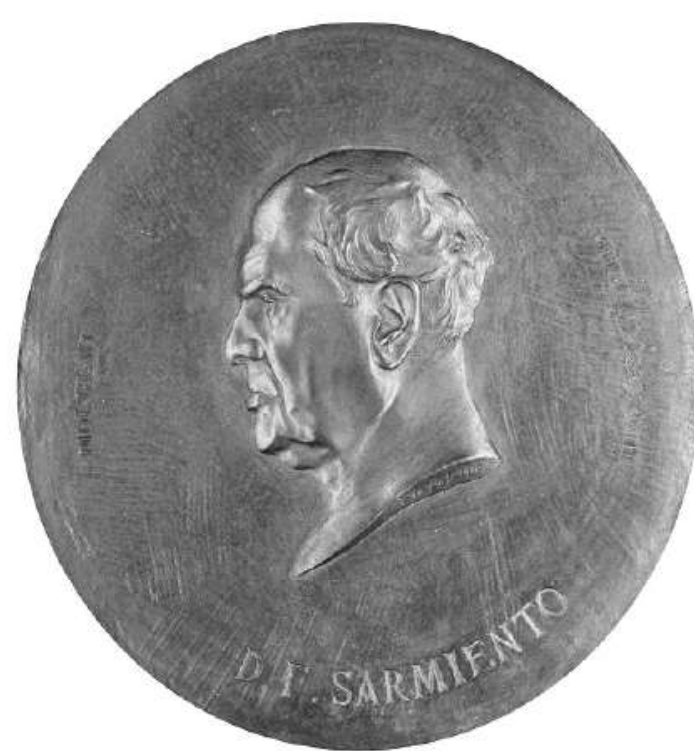

Imagen 5. Medalla conmemorativa de la inauguración del Monumento a Sarmiento por Auguste Rodin, 1900. Autor: Víctor de Pol, Colección, Museo Nacional de Bellas Artes, Argentina.

\section{La conmemoración escultórica de los "grandes hombres" en Latinoamérica}

Como ya se ha mencionado, en el antiguo régimen la efigie pública era una prerrogativa del rey. La obra más representativa de esta época en América era la estatua ecuestre de Carlos IV, ubicada en la plaza principal de la ciudad de México, hoy conocida como el zócalo, del escultor catalán Manuel Tolsá (1757-1816). Con los procesos independentistas la obra fue amenazada con ser destruida y por ello fue trasladada en 1824 al patio de la Universidad. Además de tratarse de la efigie del rey, la obra había resultado ofensiva para los criollos, pues bajo una de las patas del caballo se denigraban las armas mexicanas. Sin embargo se preservó por sus méritos técnicos y artísticos como lo demuestra su actual ubicación frente al Museo Nacional de Arte y que se conozca hoy como "el caballito de Tolsá”. La obra, que tuvo gran difusión a través del grabado de Joaquín Fabregat (1797), fue influyente para la concepción de otras obras semejantes en las capitanías de Guatemala (1808), Santiago de Cuba (1828) y Manila (1824), como parte de un corpus mayor de obras "que pueden ser calificadas de efigies exempla en torno al concepto de lealtad y actuaron como espejos de fidelidad" (Valderrama, 2013, p. 102) frente a lo acontecido en las colonias americanas independizadas.
Desde los inicios de los procesos de independencia se realizaron ceremonias que hacían explícito el cambio simbólico entre el antiguo y el nuevo régimen. Los rituales monárquicos fueron sustituidos por rituales cívicos en el que fueron centrales las arquitecturas efímeras como tablados, columnas y obeliscos con alegorías. ${ }^{4} \mathrm{Al}$ mismo tiempo que desaparecía la imagen del rey como sinónimo de Estado, surgían imágenes para reemplazarlo y dar forma al nuevo poder que se iría encarnando tanto en monedas como en banderas y escudos nacionales y solo de manera complementaria en las efigies de los héroes (Majluf, 2013, pp. 73-108). De hecho las primeras conmemoraciones escultóricas fueron en su mayoría columnas y pirámides -muchas de las cuales no pasaron de ser proyectos - que hacían referencia a los hechos más que a los protagonistas de los mismos. Una de las más tempranas que se conserva hasta hoy, aunque modificada posteriormente, es la Pirámide de mayo en Buenos Aires. La obra realizada para el primer aniversario de la revolución en 1811 se pensó para ser efímera, sin embargo subsistió, y en 1856 le fue adicionada una estatua de la libertad y cuatro alegorías de cemento (Cfr. Payró, 1970). ${ }^{6}$

Otro tipo de monumento de las primeras décadas del siglo XIX fue el de tipo alegórico, en el que también la idea está por encima de sus protagonistas. Ejemplo de ello es el Monumento a la Libertad Americana de 1829, que se encuentra desde su emplazamiento en 1836 en la Plaza de Armas de Santiago de Chile. (Imágenes 6a y 6b) Encargada por el diplomático Francisco Javier Rosales al escultor Francesco Orsolino, esta obra está inspirada en el pensamiento americanista de Andrés Bello por lo cual no se centra en la independencia chilena sino en la independencia americana utilizando para ello un recurso alegórico: Minerva, diosa de la guerra y la sabiduría, da la libertad a América. ${ }^{7}$ Con el tiempo estas alegorías territoriales fueron abandonadas en favor de alegorías de las naciones republicanas "en el estado de civilización, libertad y progreso en que se encuentran" como lo precisó el ministro plenipotenciario de Argentina ante el gobierno de Francia, Mariano Balcarce, ante la propuesta de representar a Argentina, Chile y Perú en 


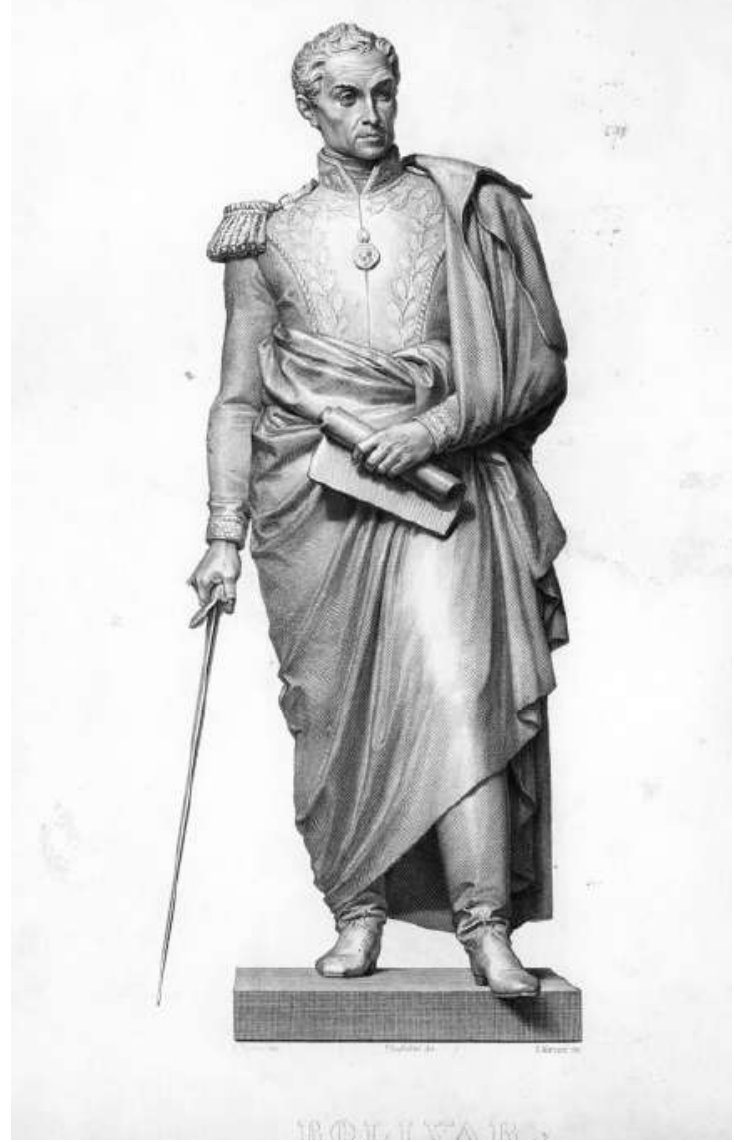

Imagen 7a. Simón Bolívar. 1845. Grabado en cobre. Autores: Pietro Tenerani / G. Marcucci. Tomado de Filipo Gerardi, Intorno alla statua di Bolivar. Livorno: Tipografía Bertani, Antonelli \& C., 1845.

fruto, entre muchas otras razones, de la centralidad que el culto a los grandes hombres representaba en la creación de las nuevas nacionalidades americanas.

Acompañando los procesos de independencia y de conformación de las nuevas naciones surgieron los primeros relatos y memorias escritos por testigos o protagonistas del momento. Como se mencionó antes, en este proceso se dio gran centralidad a las biografías de los grandes hombres construidas a partir de una selección -tal como se construía su estatua-. Las "historias patrias" y los monumentos pertenecen a un mismo género en el que hay una selección de atributos propios para la pedagogía que implican al mismo tiempo una gran cantidad de olvidos y con ello contribuyen a la unificación de la memoria nacional más allá de su propia conflictividad. Este proceso estuvo fuertemente articulado con la construcción de la ciudad y las prácticas patrióticas, ejercidas en dicho espacio en las festividades públicas, así como en la utilización de todos estos dispositivos (historias patrias, festejos y monumentos) en la educación en las escuelas. (Bertoni, 1992)

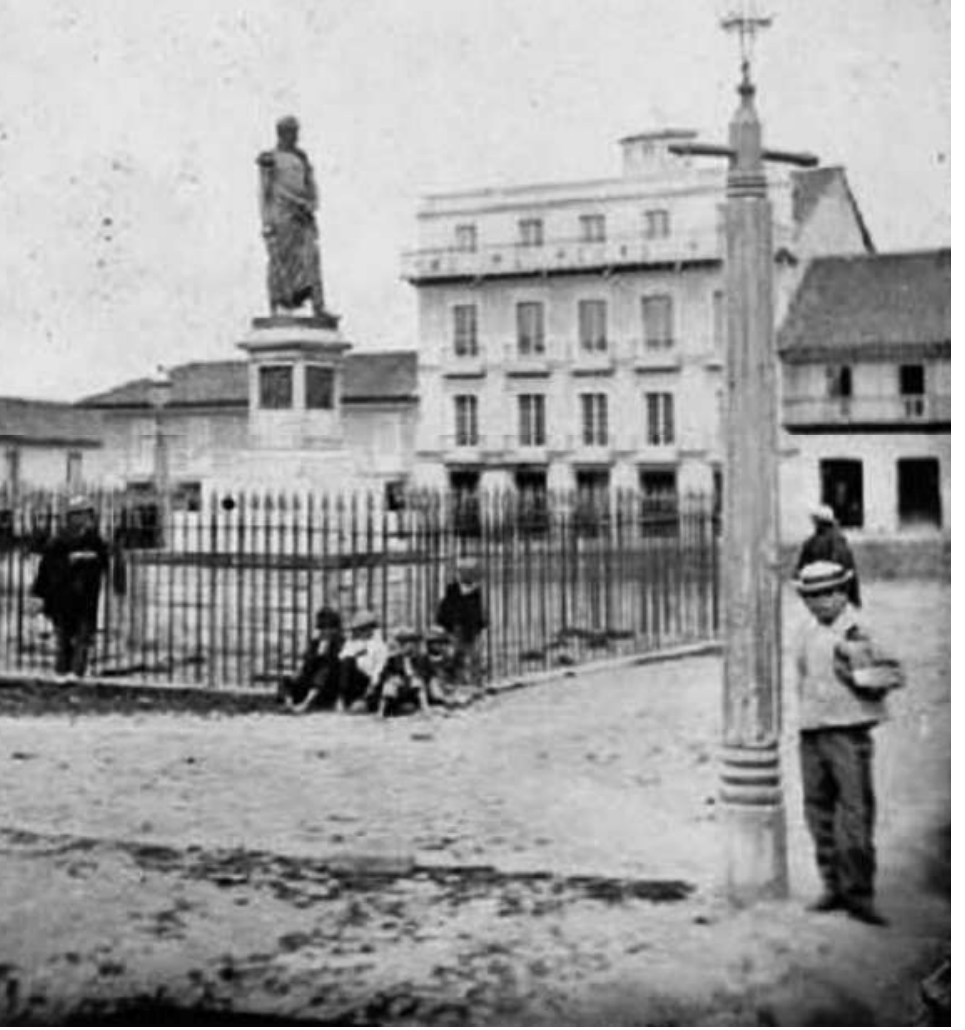

Imagen 7b: Estatua y Plaza de Bolívar. Bogotá. 1878. Anónimo. Negativo de colodión húmedo copiado en papel de gelatina. Museo Nacional de Colombia, reg. 2090.3.

Es así que el proceso de conmemoración a través de esculturas se inició con mayor fortuna con las estatuas ecuestres de indiscutidos "grandes hombres": Simón Bolívar, encargada a Adamo Tadolini e instalada en Lima en 1856 y cuya primera copia fue instalada en Caracas en 1874 (imágenes 8a y 8b); José de San Martín, encargada por el gobierno chileno a Louis-Joseph Daumas, inaugurada con modificaciones en Buenos Aires en 1862 y al año siguiente en Santiago de Chile; Pedro I, realizada por Louis Rochet e inaugurada en Río de Janeiro en 1862. Si bien ninguna estuvo exenta de discusiones locales desde el artista elegido hasta su iconografía y su ubicación, es claro que dieron paso a la práctica conmemorativa y fueron punto de partida para el posterior surgimiento de circuitos celebratorios o panteones heroicos con la ciudad como soporte. Si bien algunos programas escultóricos estuvieron marcados por un interés urbanístico, como por ejemplo el organizado en Santiago de Chile por Benjamín Vicuña Mackenna en el Parque Cousiño y particularmente el Cerro de Santa Lucía, mediante el cual el intendente pretendía construir "una especie de escenario para incorporar a Chile mediante el 


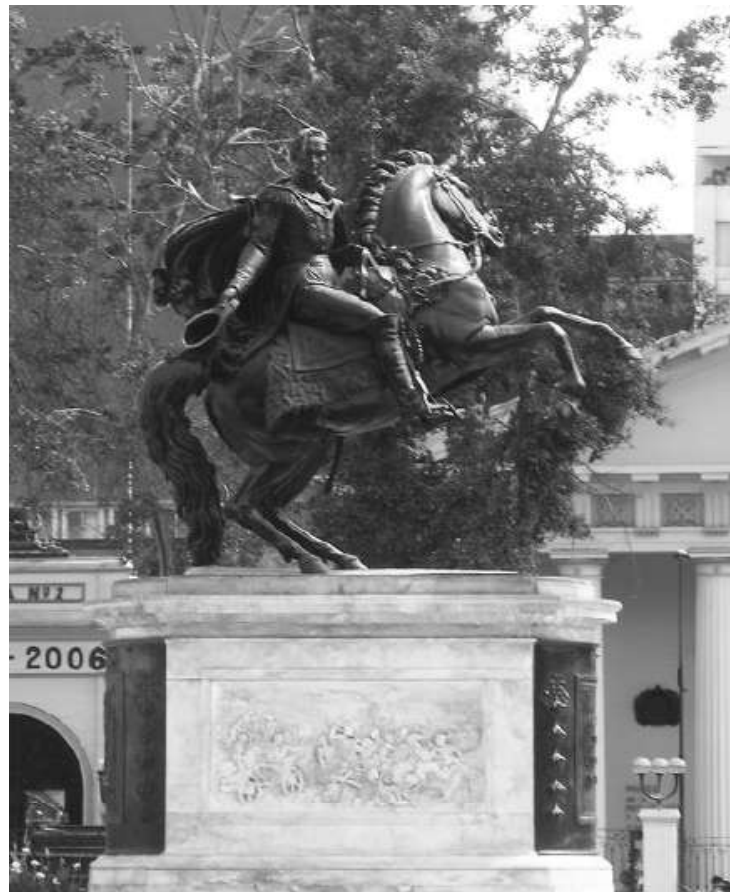

Imagen 8a. Estatua ecuestre a Simón Bolívar. 1859. Autor: Adamo Tadolini, Bronce.

Plaza Bolívar, Lima. Imagen tomada de Wikipedia. imaginario de la estatuaria al flujo histórico, cultural y artístico de Occidente" (Voionmaa, 2005, p. 120). (Imagen 9)

Para finalizar nos extenderemos sobre un caso paradigmático de la utilización de la estatuaria como estrategia auto celebratoria. Fue la del caudillo venezolano Antonio Guzmán Blanco, quien gobernó durante 18 años con cortas interrupciones entre 1870 y 1888 (Salvador, 2004). Como muchos gobernantes del momento se caracterizó por su pensamiento positivista y su fe en el progreso. Es por ello que invirtió enormemente en la construcción de grandes edificios públicos y en la modernización urbanística, dentro de la cual la construcción de estatuas era una parte fundamental. Es así que por iniciativa suya se llevó a cabo la gestión para adquirir una copia de la estatua de Bolívar de Tadolini, la cual fue realizada a partir del yeso utilizado por el artista y con aprobación del gobierno peruano. Un año antes, en 1873, el congreso había realizado un decreto de honores a Guzmán Blanco en donde se le proclamaba "ilustre americano" y "regenerador de Venezuela" junto con la creación de dos estatuas conmemorativas del mismo. Guzmán exigió hacer una revisión previa de las obras a través de fotografías y

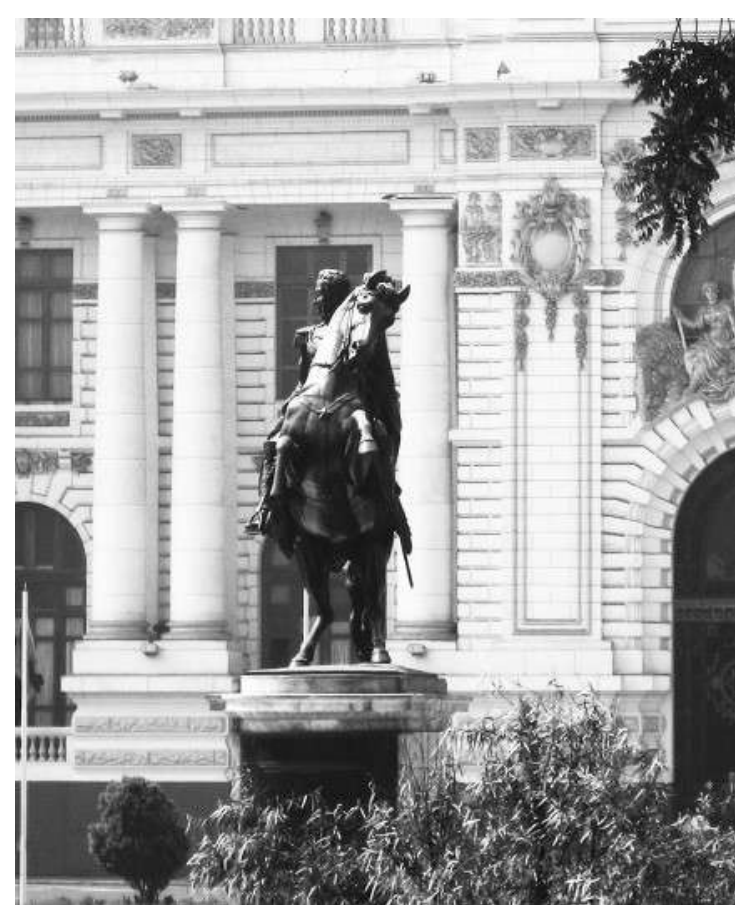

Imagen 8b. Estatua a Simón Bolívar. Lima.

Vista frontal, con el Palacio Legislativo al fondo. Fotografía de Elio Martuccelli, 2006

planeó que su estatua fuera inaugurada el mismo día que la estatua de Bolívar de Tadolini. Sin embargo por daños en el traslado de algunas piezas tuvo que posponer la inauguración de su estatua ecuestre, la cual realizó en una nueva fecha que lo vinculara con la memoria bolivariana. Tres meses después inauguró su estatua pedestre, las dos encargadas al escultor franco-norteamericano Joseph A. Bailly (1825-1883), para las cuáles le fue enviado el busto del gobernante realizado por el escultor venezolano Eloy Palacios (18471919), y realizadas bajo la supervisión oficial de otro escultor venezolano, Ramón Bolet (Salvador, 2003, pp. 113-147). (Imagen 10)

Después de la Constitución de 1874 , en la que se instituyó el periodo presidencial de dos años, Guzmán propuso al Consejo Federal la elección de Francisco Linares Alcántara, quien una vez elegido se distanció de Guzmán revocando varias de sus disposiciones, especialmente respecto a los presos políticos y a los desterrados contradictores de Guzmán. Linares falleció en extrañas circunstancias en ejercicio del cargo en noviembre de 1878 . El repudio a Guzmán Blanco se exacerbó y una asamblea nacional constituyente decretó la demolición de sus estatuas y los títulos que 


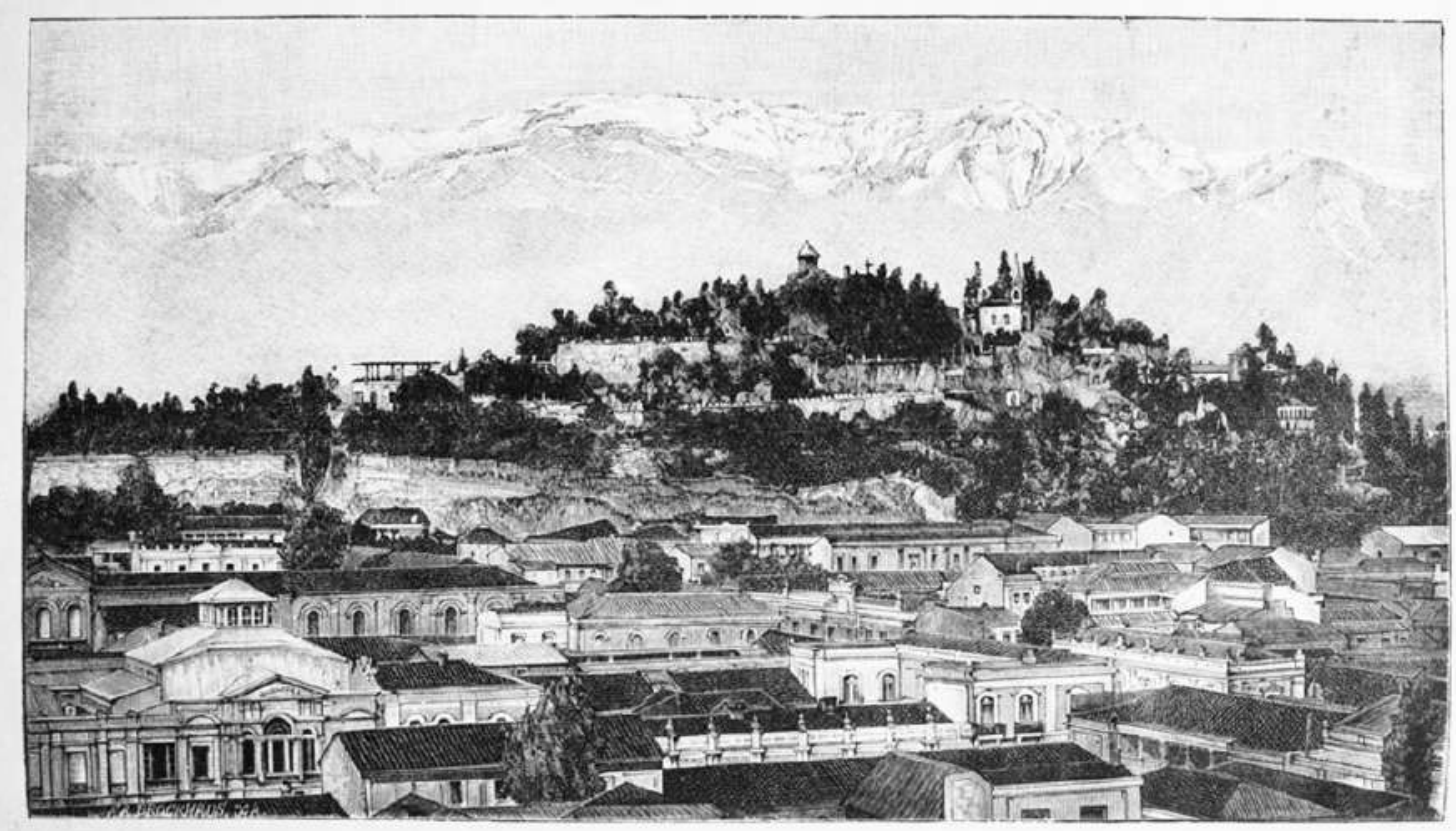

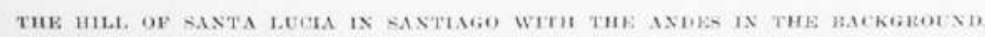

Imagen 9. Cerro Santa Lucía. 1901. Brockhaus, F.A. Santiago de Chile. Tomada de http://www.archivovisual.cl/

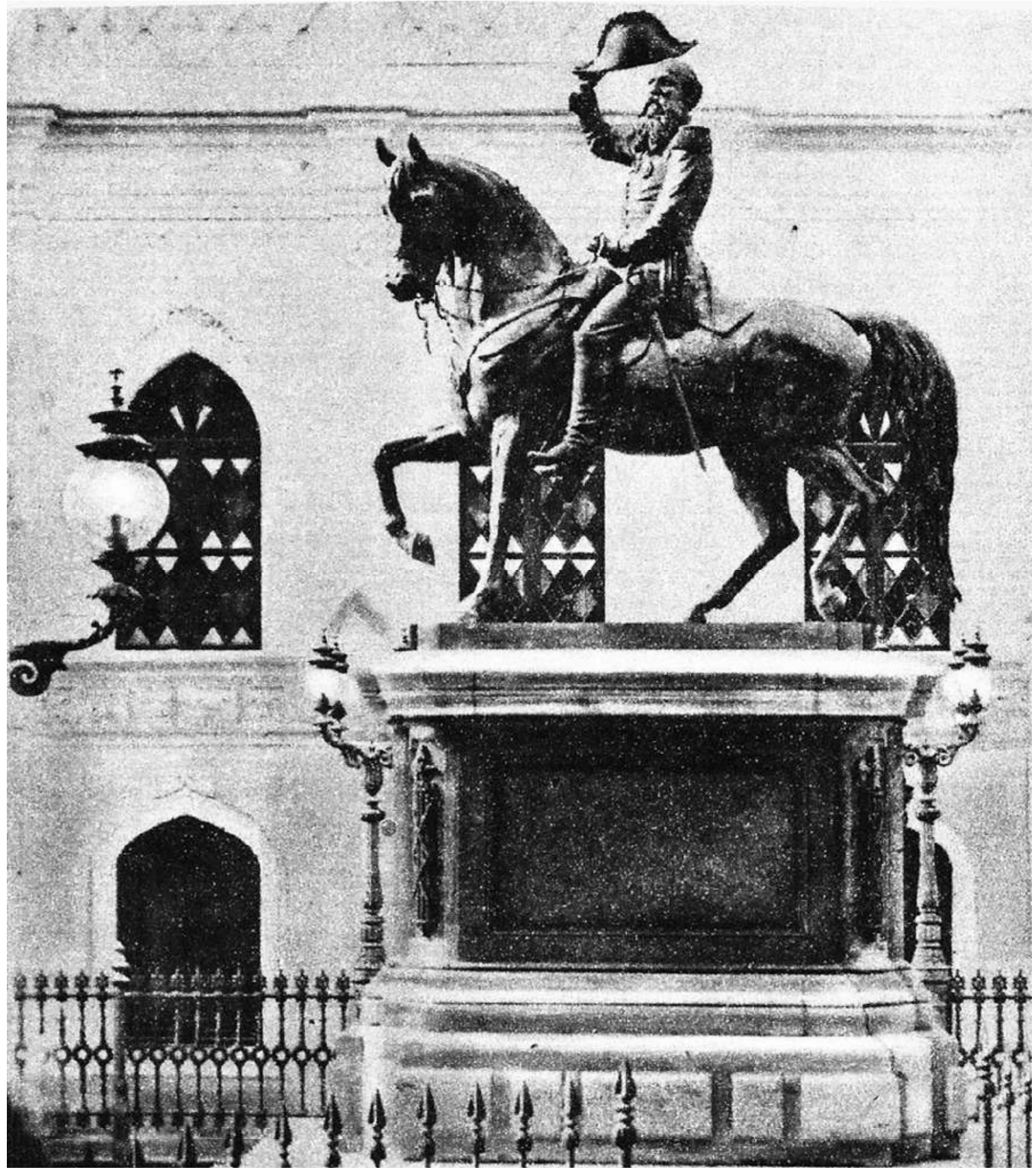

Imagen 10. Estatua ecuestre de Guzmán Blanco. Caracas. 1874. Autor: J. A. Bailly. Bronce. Destruida. Imagen tomada de http://museodeltransportecaracas.blogspot.com/2016/01/estatua-de-guzman-blanco-arriba-y-abajo.html 
se le habían otorgado. En dicho decreto quedó "para siempre prohibida en la república la erección de cualquier monumento público que tenga por objeto celebrar o enaltecer el nombre o los hechos de ningún hombre en vida". Las estatuas fueron derribadas por una turba deseosa de cumplir el decreto en diciembre de 1878 . Solo dos meses después, los fieles a Guzmán encabezados por el general Gregorio Cedeño iniciaron la restauración del régimen guzmancista y decretaron la reposición de las estatuas derrumbadas. En abril de 1879 se restituyeron todos los honores a Guzmán Blanco, incluyendo su estatua ecuestre, lo cual fue realizado, de nuevo, el día del aniversario del nacimiento de Bolívar, el 28 de octubre de 1879. Mientras se reinauguraba la obra, la comisión venezolana en París contrató una segunda estatua ecuestre de Guzmán a Albert-Ernest Carrier-Belleuse - un monumento al desagravio nacional- la cual se decidió inaugurar después en una plaza de La Guaira, pues ellos habían solicitado que se les autorizara la erección del monumento pedestre derribado en 1878 , el cual sería erigido en Valencia con toda la ritualidad correspondiente. El guzmanato termina formalmente en 1888. Al año siguiente, cuando se acercaba el natalicio de Bolívar utilizado por Guzmán para su auto glorificación, circularon rumores de que éste pretendía perseguir a sus enemigos políticos y se dio una fuerte reacción que culminó en el derrumbamiento y destrucción de las cuatro estatuas, así como la de su padre, Antonio Leocadio Guzmán, quien también había ejercido importantes cargos diplomáticos y gubernamentales en la primera mitad del XIX y a quien Guzmán Blanco había erigido una estatua en 1883. También se destruyeron numerosos retratos al óleo, litográficos y fotográficos de Guzmán Blanco, que se encontraban en todos los edificios públicos. El presidente, Juan Pablo Rojas Paúl, eludió la responsabilidad de los hechos y ordenó la reposición de la estatua de Antonio Leocadio Guzmán, aunque rechazó la posibilidad de remplazar o reparar las del “ilustre americano" (Salvador, 2006).

\section{A manera de conclusión}

La apropiación de la práctica monumental por parte de cada vez más sectores de la sociedad (juntas cívicas, parroquiales, barriales o gremiales) garantizó la reproducción del culto a la patria (Gorelik 2004 [1998], p. 211) y poco después se produjo una diversificación de los sujetos representados, al extenderse el homenaje escultórico a los intelectuales, científicos y otros "grandes hombres". Vale decir que esta práctica a un mismo tiempo consolidaba los discursos de lo nacional que sus comitentes extendían en sus proclamas, también fortalecía las ideas sobre la excepcionalidad de algunos hombres que conllevaba a un creciente proceso de discriminación por cuestiones de género, clase y "raza", además de ampliar la enorme brecha de la desigualdad que hasta hoy sigue vigente en América Latina y en el mundo. Estudiar la producción escultórica en el espacio público hoy se explica como una necesidad histórica que permite entender sus lógicas de creación y las prácticas que lo rodeaban en el momento de su mayor auge. La enorme inversión no solo económica, sino política y simbólica que los gobernantes y diferentes comunidades asociadas invirtieron en crear estas obras son un riquísimo campo aun por explorar, para superar una mirada simplista que atribuya toda escultura pública a ser entendida como "una obra oficial" erigida por quienes detentaban el poder. Como establecimos con algunos ejemplos a lo largo de este artículo, una mirada histórica, documentada y crítica puede contribuir a comprender las pugnas entre diferentes sectores por la elección de los personajes, su forma de ser representados, el lugar para ser ubicado y sus variadas recepciones. La permanencia de estas piezas en el espacio público nos confronta con un necesario estudio de la recepción de las obras a lo largo del tiempo y sus cambiantes significados, las implicaciones de sus traslados por la ciudad y sus sentidos en la urbe actual. Una aproximación de este tipo contribuiría a explicar también muchas de las iconoclasias contemporáneas (entre las que se destacan los desplazamientos y destrucciones de las estatuas de Cristóbal Colón y otros protagonistas de la llamada conquista española) además de añadir más elementos para el debate sobre cómo lidiar con los procesos de destrucción o desplazamiento, así como con los de conservación de las esculturas conmemorativas en las ciudades latinoamericanas contemporáneas. 


\section{Notas}

1 Hay pocos estudios sobre la historia de las fundiciones artísticas en América Latina. Un buen avance de lo acontecido en Rio de Janeiro puede leerse en Alberto Martín Chillón, "A fundição artística no Rio de Janeiro do segundo reinado (1840-1889)" en Tarea, no. 5, 2018. URL: http://revistasacademicas.unsam.edu.ar/index. php/tarea/article/view/445/470

2 Si bien España había reconocido la independencia del Perú en 1853, decidió ocupar las islas Chincha, emporio del guano peruano. Se produjo una alianza entre Perú, Ecuador, Chile y Bolivia para combatir esta nueva invasión que se resolvió a favor del Perú por lo que la consideran como la última de las batallas de Independencia de España.

3 “El Sarmiento de Rodin. Ni realidad ni alegoría". La Nación, 27 de mayo de 1900, p. 5. (Citado por Aguerre, 1999, p. 147)

4 Para profundizar este tema en diferentes partes de América Latina ver, por ejemplo, los casos de Argentina, (Munilla, 2013); Colombia, (Rey Márquez, 2010) y Chile, (Guzmán, 2010).

5 Es el caso del proyecto de monumento a la Batalla de Boyacá en la Nueva Granada de 1823 o el proyecto a los próceres de Guayaquil que se proyectó en 1821 y se realizó casi cien años después, en 1918. O’Higgins decretó la conmemoración con obeliscos en los lugares de las batallas de Chacabuco y Maipú en 1817 y 1818 respectivamente. Ver más ejemplos en Gutiérrez Viñuales, 2004.

\section{Referencias bibliográficas}

Abrantes, N. (1979) História da fundição artística no Brasil. Rio de Janeiro: Liboredo Fundição Artística.

Aguerre, M. (1999) Buenos Aires y sus monumentos: la presencia francesa. En: Gutman, M. y Reese, T. (eds.) Buenos Aires 1910. El imaginario para una gran capital. Buenos Aires: EUDEBA, Col. CEA.

Alves, J. F. (2009) Fontes d'Art no / au Rio Grande do Sul. Porto Alegre: Artfolio.

Beltrami, C. (2007) Carrara e l'Uruguay. En: Berresford, S. (ed.) Carrara e il mercato della scultura. Milan: Federico Motta Editore.

Bertoni, L. A. (1992) Construir nacionalidad: héroes, estatuas y fiestas patrias, 1887-1891. Boletín del Instituto de Historia Argentina y Americana "Dr. E. Ravignani" $3^{\text {a }}$ serie, $n^{\circ} 5$, 1 er semestre.

Burucúa, J. E.; Campagne, F. A. (1994). Los países del cono sur. En Annino, A.; Guerra, F.-X.; Castro Leiva, L. (dirs.) De los imperios a las naciones: Iberoamérica. Zaragoza: Caja de Ahorros y Monte de Piedad de Zaragoza, Aragón y Rioja.

Coli, J. (org.) (2010) Louis Rochet: Nova proposição apresentada à Comissão da estátua equestre de D. Pedro I, em 18 de setembro de 1856. 19\&20, Rio de Janeiro, v. $\mathrm{V}, \mathrm{n}^{\circ}$ 2, abr. Disponible en http://www. dezenovevinte.net/txt_artistas/rochet coli.htm Consultado el 28.04.2013.

Gorelik, A. (1997). La belleza de la patria. Monumentos, nacionalismo y espacio público en Buenos Aires. Block, $\mathrm{n}^{\circ} 1$, agosto.
6 La modificación fue cuestionada desde su instalación y las alegorías del comercio, la agricultura, las ciencias y las artes -de paradero actual desconocido- fueron retiradas pocos años después. Esta obra es uno de los principales lugares de memoria argentinos al ser motivo de discusión a lo largo del siglo XIX y en la celebración del Centenario en 1910 (Malosetti, 2010, pp. 450-51). Más recientemente fue revestida de nuevos significados por ser el lugar que nucleó a las "madres de plaza de mayo", quienes caminando alrededor suyo reclamaban por sus hijos desaparecidos bajo la dictadura cívico-militar (1976-1983).

7 Como lo muestra Voionmaa no son claras las condiciones del encargo y debido a la ausencia de inscripciones no se tiene certeza sobre qué acciones se representan en los bajorrelieves, interpretadas a lo largo del tiempo en clave nacional y en clave americana. Esta última es la que ha tenido mayor fortuna y desde la década de 1970 se han adicionado inscripciones en ese sentido, así como identificado tres de los bajorrelieves así: el frontal como una efigie de Simón Bolívar, el derecho como la batalla de Ayacucho y el izquierdo como la escuadra naval chilena en la expedición libertadora de 1820 (Cfr. Voionmaa, 2005, pp. 83-91).

8 Archivo Histórico del Distrito Federal, Fondo del Ayuntamiento del Distrito Federal, Sección Monumentos, vol.2276, exp. 9. Citado por Valderrama, 2010, p. 117.
(2004 [1998]) La grilla y el parque: espacio público y cultura urbana en Buenos Aires: 1887-1936. Bernal: Universidad Nacional de Quilmes.

Gutiérrez Viñuales, R. (2004) Monumento conmemorativo y espacio público en Iberoamérica. Madrid: Cuadernos Arte Cátedra.

Guzmán, F. (2010) Un monumento efímero para celebrar la independencia de Chile. $V$ Jornadas de Historia del Arte "Arte americano e Independencia. Nuevas Iconografías". Santiago de Chile: Universidad Adolfo Ibáñez, Museo Histórico Nacional, CREA y Centro Patrimonial Recoleta Dominica.

Ibarra, M. (2005) El Centenario ¿un mito urbano? (Santiago de Chile 1885-1910). Bicentenario Revista de Historia de Chile y América. Santiago de Chile, Centro de estudios Bicentenario, Vol. 4., $\mathrm{n}^{\circ} 1$.

Malosetti Costa, L. (2007 [2001]) Los primeros modernos: Arte y sociedad en Buenos Aires a fines del siglo XIX. Buenos Aires: Fondo de Cultura Económica.

--(2010) Arte e historia en el Centenario de la Revolución de Mayo en Buenos Aires. Historia Mexicana, vol. $L X, n^{\circ} 1$, julio-septiembre.

Martín Chillón, A. (2018) A fundição artística no Rio de Janeiro do segundo reinado (1840-1889). Tarea, $\mathrm{n}^{\circ}$ 5. URL: http://revistasacademicas.unsam.edu.ar/index.php/tarea/article/view/445/470

Martínez, F. (2001) El nacionalismo cosmopolita: La referencia europea en la construcción nacional en Colombia, 1845-1900. Bogotá: Banco de la República, Instituto Francés de Estudios Andinos. 
Majluf, N. (1994) Escultura y espacio público. Lima, 1850-1879. Documento de trabajo $n^{\circ}$ 67. Lima: Instituto de Estudios Peruanos.

-(2013) De cómo reemplazar a un rey: retrato, visualidad y poder en la crisis de la independencia (1808-1830). Histórica, XXXVII, 1.

Munilla La Casa, L. (2013) Celebrar y gobernar: un estudio de las fiestas cívicas en Buenos Aires, 1810-1835. Buenos Aires: Miño y Dávila.

Murilo de Carvalho, J. (1997 [1990]) La formación de las almas. El imaginario de la República en el Brasil. Buenos Aires: Universidad Nacional de Quilmes.

Payró, J. E. (1970) Prilidiano Pueyrredón, Joseph Dubourdieu, la pirámide de mayo y la catedral de Buenos $\mathrm{Ai}$ res. Buenos Aires: Universidad de Buenos Aires.

Rey Márquez, J. R. (2010) Nacionalismos aparte: antecedentes republicanos de la iconografía nacional. En VV.AA. Las historias de un grito. Doscientos años de ser colombianos. Exposición conmemorativa del Bicentenario 2010. Bogotá: Ministerio de Cultura, Museo Nacional de Colombia.

Romero, J. L. (2007) [1979] Latinoamérica: las ciudades y las ideas. Buenos Aires: Siglo XXI editores.

Salvador, J. M. (2003) Trayectoria del escultor Eloy Palacios hasta 1883. Argos, 38 , julio.

-(2004) Agravios y desagravios de un falso ídolo. Avatares de dos estatuas ecuestres de Guzmán Blanco en Caracas y La Guaira. En V Jornadas Nacionales de Investigación Humanística y Educativa, Universidad Central de Venezuela / Universidad Católica Andrés Bello, Caracas, 1-3 de diciembre.

-(2006) Construcción de un imaginario nacionalista mediante la estatuaria pública en la Venezuela de Antonio Guzmán Blanco (1870-1888). En V Jornadas de Historia Contemporánea: "Teoría e his- toria de los nacionalismos", Universidad de Oviedo, Asociación de Jóvenes Historiadores, abril.

Valderrama, N. (2013) Estatuas fieles. Ciudades ideales. El reordenamiento de las plazas de armas en Manila y La Habana. En Drien, M.; Espantoso, T.; Vanegas, C. (eds.) III Seminario Internacional sobre Arte Público en Latinoamérica. "Tránsitos, apropiaciones y marginalidades del arte público en América Latina". Santiago de Chile: Universidad Adolfo Ibáñez.

Vanegas Carrasco, C. (2011) Arte y política a mediados del siglo XIX en la Nueva Granada: el caso del “Bolívar de Tenerani”. En Cirillo, J.; Espantoso T. y Vanegas C. (orgs.) II Seminario Internacional sobre Arte Público en Latinoamérica. Arte público y espacios políticos: interacciones y fracturas en las ciudades latinoamericanas. Vitória: UFES, Comarte, 2011, pp. 231-244. Disponible en https://www.academia. edu/1216349/Arte_y_pol\%C3\%ADtica_a_mediados_ del_siglo_XIX_en_la_Nueva_Granāo_a_el_caso_ del_Bol\%C3\%ADvar_de_Tenerani_

- (2013) Mario Lambardi: una alternativa escultórica en las canteras de Balsillas. En III Seminario Internacional sobre Arte Público en Latinoamérica "Tránsitos, apropiaciones y marginalidades del arte público en América Latina". Santiago de Chile, Chile: Universidad Adolfo Ibáñez. Disponible en: https://www.academia.edu/8068599/ Drien_Marcela_Teresa_Espantoso_R._y_Carolina_ Vanegas_C._eds._III_Seminario_Internacional sobre_Arte_P\%C3\%BAblico_en_Latinoam\%C3\%Agrica_ Tr\% $3 \%$ A1nsitos_apropiaciones_y_marginalidades_ del_arte_p\%C3\%BAblico_en_Am\%C3\%Agrica_Latina_._Santiago_de_Chile_GEAP_UAI_2013

Voionmaa Tanner, L. F. (2004) Escultura pública. Santiago 1792-2004. Del monumento conmemorativo a la escultura urbana. Santiago de Chile: Ocho Libros Editores.

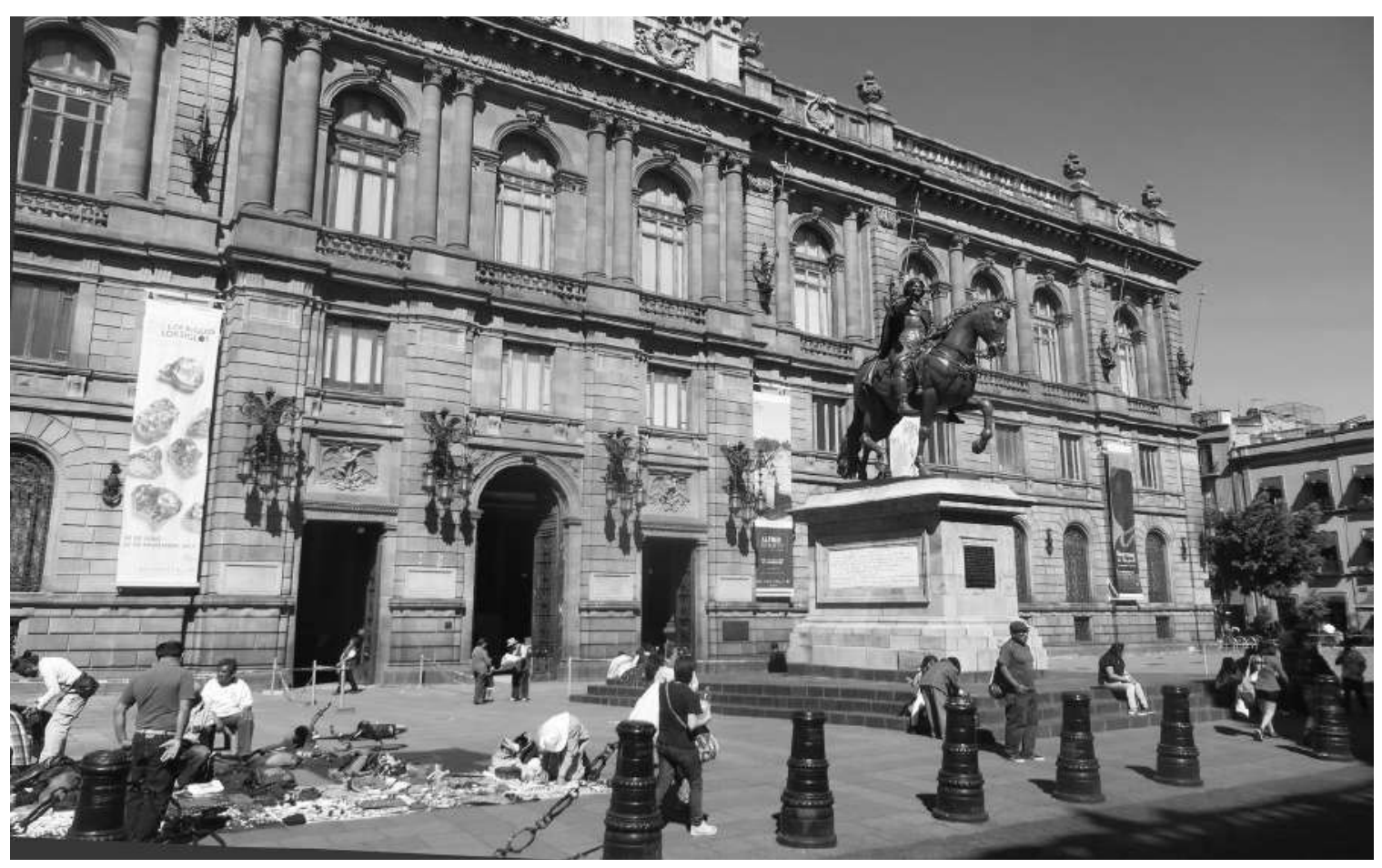

